\title{
1 Distinct physiological responses of Coccolithus braarudii life cycle phases to light \\ 2 intensity and nutrient availability
}

3

4 Gerald Langer $^{1 \dagger}$, Vun Wen Jie ${ }^{1 \dagger}$, Dorothee Kottmeier ${ }^{1}$, Serena Flori ${ }^{1}$, Daniela Sturm ${ }^{1,2}$, Joost

5 de Vries ${ }^{1,3}$, Glenn M. Harper ${ }^{4}$, Colin Brownlee ${ }^{1}$, Glen Wheeler ${ }^{1}$

6

71 The Marine Biological Association of the United Kingdom, The Laboratory, Citadel Hill,

8 Plymouth, Devon, PL1 2PB, UK

92 School of Ocean and Earth Science, University of Southampton, Southampton, SO14 3ZH, $10 \mathrm{UK}$

113 BRIDGE, School of Geographical Sciences, University of Bristol, University Road, Bristol 12 BS8 1SS, UK

134 Plymouth Electron Microscopy Centre, Brunel, Drake Circus, Plymouth, PL4 8AA

$\uparrow$ equal contribution 


\section{Abstract}

Coccolithophores feature a haplo-diplontic life cycle comprised of diploid cells producing heterococcoliths and haploid cells producing morphologically different holococcoliths. These life cycle phases of each species appear to have distinct spatial and temporal distributions in the oceans, with the heavily-calcified heterococcolithophores (HET) often more prevalent in winter and at greater depths, whilst the lightly-calcified holococcolithophores (HOL) are more abundant in summer and in shallower waters. The haplo-diplontic life cycle may therefore allow coccolithophores to expand their ecological niche, switching between life cycle phases to exploit conditions that are more favourable. However, coccolithophore life cycles remain poorly understood and fundamental information on the physiological differences between life cycle phases is required if we are to better understand the ecophysiology of coccolithophores. In this study, we have examined the physiology of HET and HOL phases of the coccolithophore Coccolithus braarudii in response to changes in light and nutrient availability. We found that the HOL phase was more tolerant to high light than the HET phase, which exhibited defects in calcification at high irradiances. The HET phase exhibited defects in coccolith formation under both nitrate $(\mathrm{N})$ and phosphate $(\mathrm{P})$ limitation, whilst no defects in calcification were detected in the HOL phase. The HOL phase grew to a higher cell density under P-limitation than N-limitation, whereas no difference was observed in the maximum cell density reached by the HET phase at these nutrient concentrations. HET cells grown under a light:dark cycle divided primarily in the dark and early part of the light phase, whereas HOL cells continued to divide throughout the $24 \mathrm{~h}$ period. The physiological differences may contribute to the distinct biogeographical distributions observed between life cycle phases, with the HOL phase potentially better adapted to high light, low nutrient regimes, such as those found in seasonally stratified surface waters.

Highlights:

- Coccolithus braarudii life cycle phases exhibit different physiological responses.

- The heavily-calcified heterococcolithophores (HET) life cycle phase is more sensitive to high light.

- The lightly-calcified holococcolithophores (HOL) life cycle phase may be better suited to growth under low phosphate availability. 


\section{Introduction}

Coccolithophores, unicellular marine algae, form a composite extracellular matrix called the coccosphere, comprised of organic material and intricately shaped calcite platelets, the coccoliths (Young et al., 2003). Coccolithophores are important primary producers (Poulton et al., 2007) and facilitate organic carbon export to the deep ocean through the ballasting effect of their coccoliths (Klaas \& Archer, 2002; Ziveri et al., 2007). They are also, together with foraminifera, the greatest contributors to pelagic carbonate sediments (Broecker \& Clark, 2009). Coccolithophores thrive in most marine environments from coastal waters to open oceanic areas and high salinity tropical seas such as the Gulf of Aqaba (Ziveri et al., 1995; Baumann et al., 2004; Tyrrell et al., 2008). The ability of coccolithophores to inhabit such diverse environments may be due in part to their specialised life cycle, although this aspect of coccolithophore biology so far remains poorly understood.

Coccolithophores exhibit a haplo-diplontic life cycle in which they can exist in alternate haploid or diploid life cycle phases that can both undergo mitotic divisions. Apart from their ploidy, the two life cycle stages are morphologically distinct. In many species, the haploid phase is lightly-calcified, producing holococcoliths that are comprised of simple rhombic crystals, whereas the diploid phase is heavily-calcified, producing heterococcoliths comprised of elaborately shaped crystals (Young et al., 2003). The holococcolithophore (HOL) phase is also motile in many species, whilst the heterococcolithophore (HET) phase is non-motile, although this distinction is not true for all species (Frada et al., 2018). The HOL and HET phases of each species have distinct spatial and temporal distributions in the environment (Supraha et al., 2016). Meta-analyses have revealed that HET tend to be most abundant in winter and at greater depths in the water column, whilst HOL are often relatively dominant in summer, particularly in surface waters (Malinverno et al., 2009; D'Amario et al., 2017). These distribution patterns strongly suggest that each life cycle phase occupies their own ecological niche, with the HOL phase most suited to nutrient-poor conditions with higher irradiances and temperatures, and the HET phase better suited to environments with lower irradiances and temperatures, and higher nutrient concentrations (de Vries et al., 2021). Whilst these distinct distribution patterns between life cycle phases can be observed in many species, it is not the case for all species. In several lineages, such as the Noelaerhabdaceae and Pleurochrysidaceae, the haploid phase is not calcified (Frada et al., 2018). As a consequence, our knowledge of the abundance and distribution of the haploid phase in these species remains very limited. 
Improved knowledge of the differential physiology of HOL and HET life cycle phases is required to fully understand the ecology and biogeography of coccolithophores. The vast majority of laboratory studies on coccolithophore physiology have focused on the HET phase with only relatively few studies directly comparing both life cycle phases (von Dassow et al., 2009; Rokitta et al., 2011). These comparative studies are primarily in Emiliania huxleyi, which is the most abundant species in modern oceans. However, E. huxleyi is not an ideal species for the broader study of coccolithophore life cycles. The HOL phase is not calcified and very little is known about its environmental distribution (Frada et al., 2012). Moreover, genomic studies suggest that many $E$. huxleyi isolates exhibit life cycle modifications and may have lost the ability to revert to the HOL phase (von Dassow et al., 2015). The HET phase of E. huxleyi often forms large blooms in stratified surface waters, typified by high irradiances and low nutrient concentrations (Zondervan, 2007). This ability of E. huxleyi HET to thrive in nutrient-depleted surface waters sets it apart from many coccolithophore species, in which the HET phase is often most abundant in deeper waters with a higher nutrient concentration (D'Amario et al., 2017).

Further comparative studies of the physiology of HOL and HET phases are therefore required to understand their distribution patterns in the field. The heavily calcified HET phases of the closely related species Coccolithus pelagicus and Coccolithus braarudii play an important role in calcite production in the North Atlantic (Daniels et al., 2016). C. pelagicus HET is found in the Arctic and subarctic regions of the Atlantic and Pacific, whereas the larger $C$. braarudii is found primarily in coastal and upwelling systems in more temperate regions (Cachao \& Moita, 2000; Saez et al., 2003; Daniels et al., 2016). A study of coccolithophore life cycle phases in the Mediterranean Sea noted that C. braarudii was primarily represented by its HOL phase, with the HET phase restricted to deeper waters in the South West Mediterranean (D'Amario et al., 2017). This suggests that $C$. braarudii HET is less suited to the warmer, oligotrophic regimes with a high irradiance that typify much of the Mediterranean. However, only very few studies have directly compared the physiology of $C$. braarudii life cycle phases. Houdan et al (2006) showed that a C. braarudii HOL isolate showed a less pronounced reduction in growth rate in low nutrient batch culture experiments (combined $\mathrm{N}$ and $\mathrm{P}$ limitation), suggesting that it is better suited to lower nutrient environments.

Whilst this is an intriguing observation, many further questions remain regarding the physiology of $C$. braarudii life cycle phases. Do they show differential sensitivity to light? 
117 How does growth under nutrient limitation compare when $\mathrm{N}$ or $\mathrm{P}$ are limited individually?

118 Are there direct impacts of light and nutrient limitation on calcification and do these effects

119 differ between the life cycle phases? The latter question is particularly relevant, as the degree

120 of calcification is clearly a major physiological difference between HET and HOL life cycle

121 phases. Coccolith morphology was unaffected by both $\mathrm{N}$ and $\mathrm{P}$ limitation in C. leptoporus

122 HET cells (Langer et al., 2012), and by P limitation in E. huxleyi HET (Oviedo et al., 2014).

123 However, $C$. braarudii HET cells showed an increase in coccolith malformations in response

124 to P limitation (Gerecht et al., 2015). An increase in coccolith malformations was also

125 observed when nitrate was replaced with urea as the N source (Benner, 2008). Moreover, it is

126 unknown whether holococcolith crystal morphology is also influenced by nutrient limitation.

127 In this study, we have set out to compare the physiology of $C$. braarudii life cycle

128 phases in response to changes in light and nutrient availability. We find that the C. braarudii

129 HET exhibits a greater sensitivity to light, exhibiting reduced growth and defective coccolith

130 morphology at high irradiances. We also find that the $C$. braarudii $\mathrm{HOL}$ is less detrimentally

131 affected by nutrient limitation than the HET phase. These distinct responses may contribute

132 to the environmental distribution of $C$. braarudii life cycle phases. 
Material and Methods

\section{Culture maintenance}

Diploid (HET) Coccolithus braarudii (PLY182g - isolated from Western English Channel station E1) was obtained from the Plymouth Culture Collection, and the haploid (HOL) strain RCC3777 (isolated from the Bay of Biscay) from the Roscoff Culture Collection (http://roscoff-culture-collection.org/). Cells were grown in dilute batch cultures in a $15^{\circ} \mathrm{C}$ controlled temperature room in $0.2 \mu \mathrm{m}$ filtered natural surface seawater sampled at E1 station off Plymouth, UK (50 $\left.02.00^{\prime} \mathrm{N}, 4^{\circ} 22.00^{\prime} \mathrm{W}\right)$ supplemented with modified K/2 media (http://www.roscoff-culture-collection.org/culture-media) with $220.5 \mu \mathrm{M}$ nitrate and 9.05 $\mu \mathrm{M}$ phosphate. Incident light intensity was $20 \mu \mathrm{mol}$ photons $\mathrm{m}^{-2} \mathrm{~s}^{-1}$ under a 16:8 h light:dark (LD) cycle. Both cultures were kept in exponential growth phase (500 to 30,000 cell ml$^{-1}$ ) monitored by cell counts using Sedgewick Rafter chamber.

\section{Light experiment}

147 Five light intensities $\left(300,50,20,10,0 \mu \mathrm{mol}\right.$ photons $\left.\mathrm{m}^{-2} \mathrm{~s}^{-1}\right)$ were applied as determined by 148 a LI-250A Photometer (LI-COR). Both life cycle stages were acclimated to 300, 50, 20 and $14910 \mu \mathrm{mol}$ photons $\mathrm{m}^{-2} \mathrm{~s}^{-1}$ respectively with an initial inoculum of 500 cells $\mathrm{ml}^{-1}$ for 5 generations. When cultures under 300, 50, 20, and $10 \mu \mathrm{mol}$ photons $\mathrm{m}^{-2} \mathrm{~s}^{-1}$ light reached a cell density of 15,000 to 20,000 cell ml$^{-1}$, the cells were inoculated into triplicate $40 \mathrm{ml}$ culture flasks with an initial cell density of 500 cell ml${ }^{-1}$. Cell density was determined daily by means of Sedgewick Rafter cell counting. Cells were harvested at 15,000 to 20,000 cells $\mathrm{ml}^{-1}$.

\section{Growth rate and discarded coccoliths to cell ratio}

To avoid bias during sampling resulting from diel changes (Kottmeier et al., 2020), sampling was done four to eight hours after the start of light phase. The growth rates were calculated as described in (Kottmeier et al., 2020) by applying exponential linear regression analysis on the growth curves:

$$
\mathrm{A}=\mathrm{A}_{0} \mathrm{e}^{\mathrm{kt}}
$$

$161 \mathrm{~A}$ and $\mathrm{A}_{0}$ are the final and initial cell densities; the growth rate is represented by $\mathrm{k}$ and $\mathrm{t}$ is 162 time [days]; e = 2.71828183. 
The discarded coccolith density was determined on harvest day for PLY182g only, because the holococcoliths produced by the haploid RCC3777 were too small for analysis. The number of discarded coccoliths per cell was determined by dividing the discarded coccolith density by the cell density.

\section{Cell Size Analysis}

Cultures were harvested at 15,000 to 20,000 cell ml$^{-1}$. For the diploid, $4 \mathrm{ml}$ of culture was decalcified with $152 \mu \mathrm{l}$ of $0.1 \mu \mathrm{M} \mathrm{HCl}$ for 2 minutes. The $\mathrm{pH}$ was later restored by the addition of $152 \mu \mathrm{l}$ of $0.1 \mu \mathrm{M} \mathrm{NaOH}$. Decalcified diploid cells were subsequently imaged using a mesolens microscope (McConnell et al., 2016). The haploid cells were also imaged with the mesolens without the need for decalcification as the protoplast can be clearly seen. For the protoplast diameter, 150 cells per biological replicate were measured using FIJI software.

\section{SEM microscopy of coccosphere and coccolith}

Cultures were filtered onto Isopore membrane filters (diameter: $13 \mathrm{~mm}$; pore size: $0.8 \mu \mathrm{m}$ ) and rinsed with distilled water (1-2 seconds) to remove seawater. The filter was quickly dried with blue roll and left in a $60^{\circ} \mathrm{C}$ oven to dry overnight. The dried samples were mounted onto aluminium stubs and sputter coated with $10 \mathrm{~nm} \mathrm{Pt/Pd} \mathrm{(Cressington,} \mathrm{USA).}$

The number of visible coccoliths per coccosphere $(n=21)$ was determined with a JEOL 6610 LV scanning electron microscope at a X4000 magnification. Coccolith morphology was classified into two categories, normal and malformed. We used a simplified categorisation compared to earlier studies (in this study 'malformed' contained the groups termed 'minor', 'major' and 'type R' (Langer et al., 2021)) as malformation levels were generally low and a high-resolution categorisation would not have provided additional information. A total of 200 coccoliths were analysed per sample. The visible coccoliths were taken to account for $75 \%$ of the total coccolith quota (Hoffmann et al., 2015). Coccolith quota and coccolith length were used to calculate PIC quota for the HET phase. SEM imaging of intact cells for the lightly-calcified HOL phase is not possible as the holococcoliths and their coccospheres are usually disrupted during SEM sample preparation. PIC quotas therefore cannot be readily calculated for the HOL phase using this approach.

\section{Particulate organic and inorganic carbon (PIC \& POC)}

The measured protoplast diameter was converted into volume according to: 


$$
V_{p}=(4 / 3) \pi \times r^{3}
$$

195

$\mathrm{V}_{\mathrm{p}}$ is the protoplast volume and $\mathrm{r}$ is the radius of the cells. The calculated volume was converted into POC quota using the equation:

$$
\mathrm{POC}\left[\mathrm{pg} \text { cell }^{-1}\right]=\mathrm{a} \times \mathrm{V}_{\mathrm{p}}^{\mathrm{b}}
$$

where $\mathrm{a}$ and $\mathrm{b}$ are constants (0.216 and 0.939 respectively) (Menden-Deuer \& Lessard, 2000). To obtain the cellular PIC quota, the volume of the coccolith is required. The following equation was used.

$$
\mathrm{Vc}=\mathrm{ks} \times \mathrm{L}^{3}
$$

Here, $\mathrm{Vc}$ is the volume of coccoliths and can be estimated using coccolith length $\mathrm{L}$ and the shape constant ks (Young \& Ziveri, 2000) which is 0.06 for $C$. braarudii. The cellular PIC quota is calculated from the following equation:

$$
\mathrm{PIC}\left[\mathrm{pg} \mathrm{cell}^{-1}\right]=\mathrm{n} \times \mathrm{Vc} \times \rho \times\left(\mathrm{Mc} / \mathrm{Mcaco}_{3}\right)
$$

where $\mathrm{n}$ is the total number of coccoliths per cell including the discarded coccoliths; $\rho$ is the calcite density of $2.7 \mathrm{pg} \mathrm{\mu m}^{-3}$ assuming coccoliths are pure calcite; $\mathrm{Mc} / \mathrm{Mcaco}_{3}$ is the molar mass ratio of $\mathrm{C}$ and $\mathrm{CaCO}_{3}$. Note that this calculation assumes a relatively constant coccolith shape and would not be appropriate for treatments that cause extensive coccolith malformations leading to a loss of the oval-shaped morphology. Although we did not specifically categorise the coccolith malformations observed in this study, malformations caused by high light were predominately minor malformations in which the oval-shape of the coccolith is maintained (see Fig. 2D). These would not be expected to greatly influence the calculation of cellular PIC quota.

\section{Dark Experiment}

For the $0 \mu \mathrm{mol}$ photons $\mathrm{m}^{-2} \mathrm{~s}^{-1}$ light treatment, an initial cell density of 15,000 cell ml${ }^{-1}$ was inoculated into standard $\mathrm{k} / 2$ media in triplicate for both life cycle phases. Cell densities were measured daily for the initial $12 \mathrm{~d}$ to determine the survivability of the cells in the absence of light and then at 34 and $60 \mathrm{~d}$.

\section{Nutrient Limitation Experiment.}

Both PLY182g and RCC3777 were grown in triplicate batch cultures in replete (control), Pand $\mathrm{N}$-limiting medium at $15^{\circ} \mathrm{C}$. The aim was to examine growth rate during exponential 
growth (a measure of growth at low nutrient concentrations prior to limitation), maximum cell density (a measure of the cellular quota of each nutrient) and the impacts on calcification. Cultures were grown in modified $\mathrm{K} / 2$ medium with $9.05 \mu \mathrm{M}$ phosphate and $220.5 \mu \mathrm{M}$ nitrate (control), initial phosphate of $1.5 \mu \mathrm{M}$ (P-limiting) or an initial nitrate of $20 \mu \mathrm{M}$ (N-limiting). The cultures were grown at an incident light intensity of $50 \mu \mathrm{mol}$ photons $\mathrm{m}^{-2} \mathrm{~s}^{-1}$ on a 16:8 h light: dark (LD) cycle. Cell density was determined daily using a Sedgewick Rafter Cell. In the nutrient limited cultures, cells were harvested in the late exponential phase, which was determined in a pre-experiment. For the control cultures, cells were harvested in exponential phase at a similar cell density to avoid differential cell density effects. For growth rate determination, only the exponential part of the growth curve was included (2-5 d).

The response of cells to nutrient replenishment was also tested. Cells were grown under initially low $\mathrm{N}$ or $\mathrm{P}$ as described above. Upon reaching stationary phase (day 8), the cultures were diluted with the initial medium in a 1:1 ratio. Growth rates were determined in the subsequent growth phase after one day (two-point).

\section{Light microscopy}

$\mathrm{P}$ and $\mathrm{N}$ - limited cells were imaged using a TMS inverted microscope with a 40x objective (Nikon, Japan), captured with an EOS 1200D camera (Canon, Japan), as well as a DMi8 inverted microscope with a 63x objective oil immersion objective (Leica, Wetzlar, Germany) and captured with an ORCA-Flash 4.0 camera (Hamamatsu, Japan).

\section{Photo-physiology measurements}

Measurements of the photosynthetic efficiency of photosystem II (Fv/Fm) were made on dark-adapted (30 min) cells using an AquaPen-C device (Photon Systems Instruments, Drásov, Czechia). All measurements were made $5 \mathrm{~d}$ after inoculation in the experimental conditions, during the phase of exponential growth. 


\section{Results}

\section{Cellular responses to light}

250

251

252

253

254

255

256

257

258

259

260

261

262

263

264

265

266

267

268

269

270

271

272

273

274

275

276

277

278

279

C. braarudii strains RCC3777 (HOL) and PLY182g (HET) were grown at light intensities ranging from 10 to $300 \mu \mathrm{mol}$ photons $\mathrm{m}^{-2} \mathrm{~s}^{-1}$. While both life cycle phases showed light saturated growth at $50 \mu \mathrm{mol}$ photons $\mathrm{m}^{-2} \mathrm{~s}^{-1}$, the specific growth rate of the HET phase significantly decreased at $300 \mu \mathrm{mol}$ photons $\mathrm{m}^{-2} \mathrm{~s}^{-1}$ whereas the growth of the HOL phase remained close to maximum (Fig. 1A). The HET cells also displayed a reduction in estimated POC and PIC production at $300 \mu \mathrm{mol}$ photons $\mathrm{m}^{-2} \mathrm{~s}^{-1}$ relative to $50 \mu \mathrm{mol}$ photons $\mathrm{m}^{-2} \mathrm{~s}^{-1}$ (Fig. 1B-C). In contrast, estimated POC production in HOL cells continued to increase with light intensity up to $300 \mu \mathrm{mol}$ photons $\mathrm{m}^{-2} \mathrm{~s}^{-1}$ (Fig. 1B). These results suggest that the HOL phase is better adapted to high light than the HET phase in terms of growth and POC production rates.

To examine whether these physiological responses were the consequence of photoinhibitory damage to the light harvesting mechanisms, we determined the photosynthetic efficiency of photosystem II in the dark-adapted state (Fv/Fm). HOL cells displayed a trend of decreasing Fv/Fm with increasing light (Fig. 1D). HET cells also exhibited a small decrease in Fv/Fm at higher irradiances, although this was not statistically significant. This suggests that the impaired growth at $300 \mu \mathrm{mol}$ photons $\mathrm{m}^{-2} \mathrm{~s}^{-1}$ in the HET phase is not a consequence of substantial photoinhibition of PSII.

To further characterize the impact of high light on calcification in the HET phase, we first measured the number of discarded coccoliths in each treatment. The morphology of the heterococcoliths is important for the structural integrity of the coccosphere, as they overlap with neighbouring coccoliths. Malformed coccoliths often fail to integrate into the coccosphere, so the number of discarded coccoliths is an indication of the extent of coccolith malformations. Cells grown at $300 \mu \mathrm{mol}$ photons $\mathrm{m}^{-2} \mathrm{~s}^{-1}$ showed a clear increase in the number of discarded coccoliths relative to all other light levels (Fig. 2A). We then analysed heterococcolith morphology in more detail using scanning electron microscopy (SEM). HET cells grown at $300 \mu \mathrm{mol}$ photons $\mathrm{m}^{-2} \mathrm{~s}^{-1}$ also showed a significant increase in the proportion of coccolith malformations compared to all other light levels (Fig. 2B-D). Holococcoliths are substantially more fragile than heterococcoliths and they tend to disintegrate during preparation for SEM analysis. Therefore, we were only able to analyse the morphology of the crystals, as opposed to the morphology of the coccolith as a whole or the integrity of the 
coccosphere. Crystal morphology in holococcoliths from HOL cells grown at $300 \mu \mathrm{mol}$ photons $\mathrm{m}^{-2} \mathrm{~s}^{-1}$ was not different from the crystals grown at the lower light intensities $(97.8 \pm$ $1.7 \%$ crystals exhibited normal morphology, compared to $>96 \%$ in all other samples) (Supplementary Fig. 1). Overall, these results suggest that calcification in the HET phase is sensitive to high light, leading to a decrease in PIC production and impacts on coccolith morphogenesis and the structural integrity of the coccosphere.

The HOL phase may therefore be better suited to higher light environments than the HET phase. This is consistent with the distribution of $C$. braarudii life cycle phases in the field, both spatially (depth) and temporally (seasonal irradiance) (D'Amario et al., 2017). However, it is notable the HET phase did not grow better than the HOL under very low light conditions $\left(10 \mu \mathrm{mol}\right.$ photons $\left.\mathrm{m}^{-2} \mathrm{~s}^{-1}\right)$. We therefore examined the ability of both life phases cycle stages to survive in an extended period of darkness, which may be beneficial for cells occupying a deeper position in the water column. We found that cell density decreased rapidly in the HOL phase after 7 days in darkness, with cell density approaching zero after 10 days (Fig. 3). In contrast, the cell density of the HET phase did not decrease for the entire 60 day duration of the experiment (Fig. 3). Microscopic observation indicated that HET cells remained pigmented throughout. Thus, the HET phase is able to survive in the absence of a photosynthetic supply of energy during extended periods of darkness.

\section{Response to nutrient limitation}

We next examined the growth of the HET and HOL phases of $C$. braarudii under nutrient limiting conditions. We grew $C$. braarudii life cycle phases in batch or semi-continuous culture with limiting concentrations of $\mathrm{N}$ or $\mathrm{P}(20 \mu \mathrm{M}$ or $1.5 \mu \mathrm{M}$ respectively). These culturing approaches have distinct advantages and disadvantages when studying nutrient limitation (Langer et al., 2012; Langer et al., 2013; Gerecht et al., 2015). In batch culture experiments, nutrient concentrations decline throughout the experiment, as they are taken up by the cells and not replenished in the media (Langer et al., 2013). However, the maximum cell density reached can be used as an indication of the minimum cell quota of a limiting nutrient (Perrin et al., 2016). The HOL phase grew to a higher cell density under P limitation relative to $\mathrm{N}$ limitation, whereas the cell densities obtained by the HET phase were very similar under both $\mathrm{N}$ - and P-limitation (Fig. 4A-B). 
Growth rate is another important ecological parameter, although this can only be determined reliably in the exponential phase of a batch culture. This puts considerable restrictions on the interpretation, because the nutrient limitation effects are comparatively weak in the exponential phase, with the cells only becoming severely nutrient depleted in the transition phase or early stationary phase (Langer et al., 2012). Growth rate in the exponential phase of a batch culture therefore reflects the ability of cells to grow in low but not necessarily limiting nutrient concentrations. There was no significant effect of low $\mathrm{N}$ or $\mathrm{P}$ on the growth rate of HOL or HET cells (Fig. 4C).

We next examined growth in response to nutrient replenishment. Batch cultures that were exhibiting $\mathrm{N}$ - or P-limited growth (day 8 ) were diluted with an equal volume of fresh media containing low concentrations of $\mathrm{N}$ or $\mathrm{P}(20 \mu \mathrm{M}$ or $1.5 \mu \mathrm{M}$ respectively). We found that the growth rate of HET cells was restored to similar values following either $\mathrm{N}$ or $\mathrm{P}$ replenishment ( $74.7 \%$ or $82.3 \%$ respectively of the nutrient replete control), whereas in HOL cells, replenishment of $\mathrm{P}$ led to a much greater increase in growth rate (128.6\% of a nutrient replete control) compared to $\mathrm{N}$ replenishment (97.0\% of control) (Fig. 5). This suggests that the HOL phase is able to respond more quickly to a restoration of nutrient availability following nutrient limitation, particularly when $\mathrm{P}$ is resupplied. These are likely to be beneficial attributes in areas of low or episodic nutrient supply.

The impact of nutrient limitation on heterococcolith morphology has been a long standing question. Analysis of coccoliths in environmental samples led to suggestions that nutrient limitation may result in coccolith malformations (Okada \& Honjo, 1975; Kleijne, 1990). Experimental studies subsequently confirmed this hypothesis for P limitation in the $C$. braarudii HET (Gerecht et al., 2015). We therefore analysed heterococcolith morphology in nutrient-limited cells from our batch culture experiments. We found that $\mathrm{P}$ - as well as $\mathrm{N}$ limitation caused an increase in the percentage of discarded coccoliths per cell and a substantial increase in the percentage of coccoliths exhibiting malformations (Fig. 6A-B). P limitation had a more severe effect than $\mathrm{N}$ limitation for both of these metrics. Whilst we could not directly compare these parameters in the HOL phase, we examined the crystal morphology of holococcoliths. All treatments displayed predominately normal crystals (Fig. 6C, Supplementary Fig. 2). However, it was noticeable that HOL cells grown under P limitation had more complete coccospheres than control or N-limited cells (Fig. 6D). Although we were not able to quantify this effect directly, it again points to the tendency of the HOL phase to perform better under $\mathrm{P}$ limitation than $\mathrm{N}$ limitation. 


\section{Timing of cell division in the diel cycle}

346 E. huxleyi HET cells grown under a light-dark cycle become synchronised, with cell division

347 occurring primarily in the dark phase although it can continue for several hours after the

348 onset of the light phase (Muller et al., 2008; Kottmeier et al., 2020). Calcification occurs

349 primarily in the light, with the rate of calcification tightly correlated to the percentage of cells

350 in the G1 phase of the cell cycle (Muller et al., 2008). We therefore examined the nature of

351 cell division in HOL and HET phases of $C$. braarudii to see if this was influenced by the

352 light-dark cycle (16:8). Similar to previous observations of E. huxleyi HET (Kottmeier et al.,

353 2020), C. braarudii HET showed only a small increase in cell density during the light phase,

354 with the majority of cell division occurring in the dark phase (Fig. 7). In contrast, HOL cells

355 showed a linear increase in cell density throughout the light-dark cycle. Continuous, rather

356 than synchronised, cell division in the HOL phase could also explain why the HOL phase is

357 able to show an improved growth rate under repeated nutrient replenishment in the semi-

358 continuous culture (Fig. 5). 


\section{Discussion}

361 Our results demonstrate that $C$. braarudii life cycle phases exhibit distinct responses to changes in irradiance. The HET phase was notably sensitive to higher irradiances, showing an optimum of $50 \mu \mathrm{mol}$ photons $\mathrm{m}^{-2} \mathrm{~s}^{-1}$ across the tested range. This suggests that the natural populations of $C$. braarudii HET could encounter irradiances above optimal levels in surface waters in the N. Atlantic, although they would be much less likely to encounter excess light lower in the water column as PAR attenuates rapidly with depth (Poulton et al., 2010). The greater sensitivity of HET phase to light is therefore in keeping with its expected distribution in the water column (D'Amario et al., 2017). As the HET phase did not show a decline in the performance of photosystem II under high light, the direct cause of the greater sensitivity of the HET phase to light remains unclear. One possibility is that the high demand for dissolved inorganic carbon for photosynthesis may compete with the carbon supply for calcification (Bach et al., 2013; Bolton \& Stoll, 2013).

The response of other coccolithophore species to light has been studied most extensively in E. huxleyi. E. huxleyi HET blooms primarily in surface waters during mid-summer and high irradiance has been identified as an important contributory factor in bloom formation (Nanninga \& Tyrrell, 1996; Tyrrell \& Merico, 2004). Accordingly, laboratory studies indicate that E. huxleyi (HET) is highly tolerant to higher irradiances (Ragni et al., 2008; Loebl et al., 2010; Gafar \& Schulz, 2018). The E. huxleyi HOL phase is more sensitive to light, exhibiting photoinhibition at light intensities above $400 \mu \mathrm{mol}$ photons $\mathrm{m}^{-2} \mathrm{~s}^{-1}$ (Houdan et al., 2005). The greater sensitivity of E. huxleyi HOL to light is therefore in sharp contrast with the findings from $C$. braarudii and seem to run counter to the expectation from many coccolithophore species that HOL prefer higher light compared to the HET. However, our very limited knowledge of the ecological distribution of the E. huxleyi HOL means that we cannot determine whether the physiological differences between life cycle phases in this species reflect adaptation to different environments. Gephyrocapsa oceanica is closely related to E. huxelyi and its HET phase is similarly tolerant of high irradiances (Zhang et al., 2015). There are relatively few laboratory studies of light tolerance in the coccolithophore species found at greater depths, although Scyphosphaera apsteinii HET appears to be lowlight adapted with growth optima around $100 \mu \mathrm{mol}$ photons $\mathrm{m}^{-2} \mathrm{~s}^{-1}$ (Drescher et al., 2012; 
391

392

393

394

395

396

397

398

399

400

401

402

403

404

405

406

407

408

409

410

411

412

413

414

415

416

417

418

419

420

421

422

423

The C. braarudii HET phase showed a remarkable ability to survive in darkness. This ability could be ecologically relevant in life cycle phases that occupy a deeper position in the water column or inhabit high latitude regions, which experience extended periods of darkness in winter months. Whilst $C$. braarudii HET is not typically found in very high latitudes, the closely related $C$. pelagicus HET is abundant in Artic and subarctic waters. We do not yet know why $C$. braarudii HET cells are able to survive longer in darkness. In extended darkness, one strategy polar phytoplankton use to provide organic nutrients is mixotrophy (McKie-Krisberg \& Sanders, 2014; Stoecker \& Lavrentyev, 2018). However, previous studies suggest that bacterivory is most likely to be exhibited by the C. braarudii HOL phase rather than the HET phase, although this ability has also been observed in the HET phase of some other placolith bearing coccolithophores (Houdan et al., 2006; Avrahami \& Frada, 2020). It therefore appears unlikely that dark survival of the HET is due to improved ability to acquire nutrients via bacterivory relative to the HOL phase. Dark survival of the HET phase may therefore be due to another aspect of physiology, such as an improved capacity to utilise stored lipids, carbohydrates or proteins as organic carbon sources, as observed in some polar diatoms (Schaub et al., 2017). A recent study demonstrated that dark survival in HET coccolithophores was supported by osmotrophy of organic carbon compounds (Godrijan et al., 2022). The trends observed in the physiological responses of the $C$. braarudii life cycle phases to light are therefore broadly consistent with their different seasonal and geographical distributions.

There were also indications from our experiments that the HOL phase was better suited to low nutrient environments, although this was observed primarily under P-limitation rather than N-limitation. In particular, the higher cell density achieved by HOL cells under Plimitation suggest a low minimum cell quota for $\mathrm{P}$ that may be advantageous in environments where $\mathrm{P}$ availability is low. Transcriptomic and metabolomic studies of $\mathrm{N}$-limitation in $E$. huxleyi indicate an overall decrease in growth and biosynthetic capacity in both life cycle phases, presumably due to the lack of available $\mathrm{N}$ for protein synthesis (Rokitta et al., 2014; Wordenweber et al., 2018). Whilst P-limited E. huxleyi cells displayed some shared metabolic responses with N-limited cells (Rokitta et al., 2016), it is thought that a primary consequence of P-limitation is the inability to synthesise P-rich nucleic acids, which limits growth but not necessarily other aspects of metabolism (Wordenweber et al., 2018). Some of the major consequences of P-limitation in E. huxleyi HET are lipid remodelling to reduce phospholipid content and the activation of P-scavenging enzymes such as alkaline 
phosphatase (Shemi et al., 2016). It is interesting that significant differences in the expression of these P-acquisition genes was observed between $E$. huxleyi life cycle phases, which may contribute to the greater ability of HOL cells to resist P-limitation (Rokitta et al., 2016). The lower DNA content in the haploid genome of HOL cells may also contribute to a lower Prequirement that would provide an advantage under P-limitation (Rokitta et al., 2016). A combination of these factors may therefore contribute to the improved growth of the $C$. braarudii HOL under P limitation observed in our experiments.

A notable consequence of both light and nutrient stress in the HET phase was the disruption of coccolith morphology. Both $\mathrm{N}$ and $\mathrm{P}$ limitation had a detrimental effect on heterococcolith crystal morphology while they had no effect on holococcolith crystal morphology. The response to light is surprising because there is no obvious mechanistic connection between the morphogenetic machinery and light intensity. The impaired morphogenesis in the HET $C$. braarudii under $300 \mu \mathrm{mol}$ photons $\mathrm{m}^{-2} \mathrm{~s}^{-1}$ is ecologically relevant because light intensities in the surface mixed layer can be higher than $300 \mu \mathrm{mol}$ photons $\mathrm{m}^{-2} \mathrm{~s}^{-1}$ (Nanninga \& Tyrrell, 1996), and aberrant coccolith morphology might impair coccosphere architecture and cell division (Walker et al., 2018). The findings suggest that holococcolith formation does not require the cellular mechanisms within heterococcolith formation that are sensitive to excess light or nutrient limitation. It can be hypothesized that the HOL crystal shaping machinery is simpler and is less easily disturbed by differing demands on cellular resources such as inorganic carbon, $\mathrm{N}$ and $\mathrm{P}$. This hypothesis fits the observation that holococcolith crystals are all rhombic and of the same relatively small size (species independent), while heterococcolith crystals display complex shapes and sizes that can even vary within a single coccolith (Young et al., 2003). The relative insensitivity of holococcolith morphogenesis to environmental stress might be one advantage of the HOL phase in certain habitats.

Calcification is clearly a major physiological difference between the $C$. braarudii life cycle phases and it may also contribute to the observed differences in the timing of cell division. Both heterococcoliths and holococcoliths are primarily produced in the light phase of the diel cycle (Paasche, 1969). Production of each single large heterococcolith in the HET phase takes approximately three hours, whereas holococcolith production is much more rapid (Taylor et al., 2007; Langer et al., 2021). It seems likely that the extensive rearrangement of the cytoskeleton required for cell division would interfere with its essential role in heterococcolith formation (Langer et al., 2010; Durak et al., 2017) and intracellular heterococcoliths are not observed in dividing HET cells (Walker et al., 2018). Therefore 
heterococcolith formation and cell division are temporally separated in the HET phase, with the former occurring primarily in the light and the latter restricted to the dark phase of the diel cycle. This distinction is not found in the HOL phase, which appears to divide throughout the diel cycle. The ability to generate and secrete mature holococcoliths very rapidly means that cell division would not cause a lengthy disruption of the calcification process. It is possible that the lack of synchronisation of cell division in the HOL phase may allow for enhanced growth rates under certain conditions, such as the response to pulsed nutrient additions in low nutrient regimes.

Our results identify some important physiological differences between two C. braarudii life cycle phases, 182g (HET) and RCC3777 (HOL). Our results broadly support the conclusion of Houdan et al (2006) who also observed lower sensitivity of the HOL phase to macronutrient limitation. The physiological differences are striking because they are closely aligned to expectations based on the differing environmental distributions of $C$. braarudii life cycle phases (Cros \& Estrada, 2013; Supraha et al., 2016; D'Amario et al., 2017). By exhibiting distinct physiology between life cycle phases, C. braarudii and other coccolithophores can occupy a broader ecological niche (de Vries et al., 2021). However, it is important to note that our findings are based on the observation of two distinct environmental isolates. Whilst both strains were isolated from a similar geographic location (NE Atlantic), it is possible that they have a degree of inherent variability in their sensitivity to various stressors. This is largely unavoidable in laboratory comparisons of phytoplankton strains, but this is an important caveat to our findings. Future studies examining further isolates or ideally isogenic HET-HOL pairs isolated from the same culture (Houdan et al., 2006) will be needed to further verify our observations. 
481 Acknowledgements. We thank Malcolm Woodward (Plymouth Marine Laboratory, UK) for help with nutrient analyses.

484 Disclosure statement. The authors declare no competing interests.

485

486 Funding Authors. The work was supported by an NERC award to GLW (NE/N011708/1)

487 and an ERC Advanced Grant to CB (ERC-ADG-670390).

488

489 Author contributions. G. Langer: original concept, all experimental analyses, drafting and

490 editing manuscript; VW Jie: all experimental analyses; D Kottmeier: cell division

491 experiment; S Flori: cell division experiment; D Sturm: analysis of nutrient limitation

492 experiments; J de Vries: analysis of nutrient limitation experiments; G Harper: electron

493 microscopy; C Brownlee: drafting and editing manuscript: G Wheeler original concept,

494 drafting and editing manuscript. 
References

Avrahami, Y. \& Frada, M.J. (2020). Detection of phagotrophy in the marine phytoplankton group of the coccolithophores (Calcihaptophycidae, Haptophyta) during nutrient-replete and phosphate-limited growth. Journal of Phycology, 56:1103-1108. Bach, L.T., Mackinder, L.C.M., Schulz, K.G., Wheeler, G., Schroeder, D.C., Brownlee, C., \& Riebesell, U. (2013). Dissecting the impact of $\mathrm{CO}_{2}$ and $\mathrm{pH}$ on the mechanisms of photosynthesis and calcification in the coccolithophore Emiliania huxleyi. New Phytologist 199: 121-134.

Baumann, K.H., Bockel, B., \& Frenz, M. (2004). Coccolith contribution to south Atlantic carbonate sedimentation. Coccolithophores: From Molecular Processes to Global Impact: (Thierstein, H.R, Young J.R. eds), 367-402. Springer, Berlin. Benner, I. (2008). The utilization of organic nutrients in marine phytoplankton with emphasis on coccolithophores. (PhD thesis), 1-125. Universitat Bremen.

510 Bolton, C.T. \& Stoll, H.M. (2013). Late Miocene threshold response of marine algae to carbon 511 dioxide limitation. Nature 500: 558-562. Broecker, W. \& Clark, E. (2009). Ratio of coccolith $\mathrm{CaCO}_{3}$ to foraminifera $\mathrm{CaCO}_{3}$ in late Holocene deep sea sediments. Paleoceanography 24: PA3205. Cachao, M. \& Moita, M.T. (2000). Coccolithus pelagicus, a productivity proxy related to moderate fronts off Western Iberia. Marine Micropaleontology 39: 131-155.

Cros, L. \& Estrada, M. (2013). Holo-heterococcolithophore life cycles: ecological implications. Marine Ecology Progress Series 492: 57-68.

518 D'Amario, B., Ziveri, P., Grelaud, M., Oviedo, A., \& Kralj, M. (2017). Coccolithophore haploid and diploid distribution patterns in the Mediterranean Sea: can a haplo-diploid life cycle be advantageous under climate change? Journal of Plankton Research 39: 781-794. Daniels, C.J., Poulton, A.J., Young, J.R., Esposito, M., Humphreys, M.P., Ribas-Ribas, M., Tynan, E., \& Tyrrell, T. (2016). Species-specific calcite production reveals Coccolithus pelagicus as the key calcifier in the Arctic Ocean. Marine Ecology Progress Series 555: 2947.

De Vries, J., Monteiro, F., Wheeler, G., Poulton, A., Godrijan, J., Cerino, F., Malinverno, E., Langer, G., \& Brownlee, C. (2021). Haplo-diplontic life cycle expands coccolithophore niche. Biogeosciences 18: 1161-1184.

Drescher, B., Dillaman, R.M., \& Taylor, A.R. (2012). Coccolithogenesis in Scyphosphaera apsteinii (Prymnesiophyceae). Journal of Phycology 48: 1343-1361.

530 Durak, G.M., Brownlee, C., \& Wheeler, G.L. (2017). The role of the cytoskeleton in 531 biomineralisation in haptophyte algae. Scientific Reports 7. Frada, M.J., Bendif, E.M., Keuter, S., \& Probert, I. (2018). The private life of coccolithophores. Perspectives in Phycology 6: 11-30.

Frada, M.J., Bidle, K.D., Probert, I., \& De Vargas, C. (2012). In situ survey of life cycle phases of the coccolithophore Emiliania huxleyi (Haptophyta). Environmental Microbiology 14: 15581569 .

Gafar, N.A., Eyre, B.D., \& Schulz, K.G. (2019). A comparison of species specific sensitivities to changing light and carbonate chemistry in calcifying marine phytoplankton. Scientific Reports 9: 2486.

Gafar, N.A. \& Schulz, K.G. (2018). A three-dimensional niche comparison of Emiliania huxleyi and Gephyrocapsa oceanica: reconciling observations with projections. Biogeosciences 15: 3541-3560. 
Gerecht, A.C., Supraha, L., Edvardsen, B., Langer, G., \& Henderiks, J. (2015). Phosphorus availability modifies carbon production in Coccolithus pelagicus (Haptophyta). Journal of Experimental Marine Biology and Ecology 472: 24-31. Godrijan, J., Drapeau, D.T., \& Balch, W.M. (2022). Osmotrophy of dissolved organic carbon by coccolithophores in darkness. New Phytologist 233: 781-794.

Hoffmann, R., Kirchlechner, C., Langer, G., Wochnik, A.S., Griesshaber, E., Schmahl, W.W., \& Scheu, C. (2015). Insight into Emiliania huxleyi coccospheres by focused ion beam sectioning. Biogeosciences 12: 825-834.

Houdan, A., Probert, I., Van Lenning, K., \& Lefebvre, S. (2005). Comparison of photosynthetic responses in diploid and haploid life-cycle phases of Emiliania huxleyi (Prymnesiophyceae). Marine Ecology Progress Series 292: 139-146.

Houdan, A., Probert, I., Zatylny, C., Veron, B., \& Billard, C. (2006). Ecology of oceanic coccolithophores. I. Nutritional preferences of the two stages in the life cycle of Coccolithus braarudii and Calcidiscus leptoporus. Aquatic Microbial Ecology 44: 291-301.

Klaas, C. \& Archer, D.E. (2002). Association of sinking organic matter with various types of mineral ballast in the deep sea: Implications for the rain ratio. Global Biogeochemical Cycles 16: 1116.

Kleijne, A. (1990). Distribution and malformation of extant calcareous nannoplankton in the Indonesian seas. Marine Micropaleontology 16: 293-316.

Kottmeier, D.M., Terbruggen, A., Wolf-Gladrow, D.A., \& Thoms, S. (2020). Diel variations in cell division and biomass production of Emiliania huxleyi - Consequences for the calculation of physiological cell parameters. Limnology and Oceanography 65: 1781-1800.

Langer, G., De Nooijer, L.J., \& Oetjen, K. (2010). On the role of the cytoskeleton in coccolith morphogenesis: the effect of cytoskeleton inhibitors. Journal of Phycology 46: 1252-1256.

Langer, G., Oetjen, K., \& Brenneis, T. (2012). Calcification of Calcidiscus leptoporus under nitrogen and phosphorus limitation. Journal of Experimental Marine Biology and Ecology 413 : 131-137.

Langer, G., Oetjen, K., \& Brenneis, T. (2013). Coccolithophores do not increase particulate carbon production under nutrient limitation: A case study using Emiliania huxleyi (PML B92/11). Journal of Experimental Marine Biology and Ecology 443: 155-161.

Langer, G., Taylor, A.R., Walker, C.E., Meyer, E.M., Ben Joseph, O., Gal, A., Harper, G.M., Probert, I., Brownlee, C., \& Wheeler, G.L. (2021). Role of silicon in the development of complex crystal shapes in coccolithophores. New Phytologist. 231: 1845-1857.

Loebl, M., Cockshutt, A.M., Campbell, D.A., \& Finkel, Z.V. (2010). Physiological basis for high resistance to photoinhibition under nitrogen depletion in Emiliania huxleyi. Limnology and Oceanography 55: 2150-2160.

Malinverno, E., Triantaphyllou, M.V., Stavrakakis, S., Ziveri, P., \& Lykousis, V. (2009). Seasonal and spatial variability of coccolithophore export production at the South-Western margin of Crete (Eastern Mediterranean). Marine Micropaleontology 71: 131-147.

McConnell, G., Tragardh, J., Amor, R., Dempster, J., Reid, E., \& Amos, W.B. (2016). A novel optical microscope for imaging large embryos and tissue volumes with sub-cellular resolution throughout. Elife 5: e18659.

Mckie-Krisberg, Z.M. \& Sanders, R.W. (2014). Phagotrophy by the picoeukaryotic green alga Micromonas: implications for Arctic Oceans (vol 8, pg 1953, 2014). ISME Journal 8: 21512151.

Menden-Deuer, S. \& Lessard, E.J. (2000). Carbon to volume relationships for dinoflagellates, diatoms, and other protist plankton. Limnology and Oceanography 45: 569-579.

Muller, M.N., Antia, A.N., \& Laroche, J. (2008). Influence of cell cycle phase on calcification in the coccolithophore Emiliania huxleyi. Limnology and Oceanography 53: 506-512. 
Nanninga, H.J. \& Tyrrell, T. (1996). Importance of light for the formation of algal blooms by Emiliania huxleyi. Marine Ecology Progress Series 136: 195-203.

Okada, H. \& Honjo, S. (1975). Distribution of coccolithophores in marginal seas along Western Pacific Ocean and in Red-Sea. Marine Biology 31: 271-285.

Oviedo, A.M., Langer, G., \& Ziveri, P. (2014). Effect of phosphorus limitation on coccolith morphology and element ratios in Mediterranean strains of the coccolithophore Emiliania huxleyi. Journal of Experimental Marine Biology and Ecology 459: 105-113.

Paasche, E. (1969). Light-dependent coccolith formation in the two forms of Coccolithus pelagicus. Archives Mikrobiology 67: 199-208.

Perrin, L., Probert, I., Langer, G., \& Aloisi, G. (2016). Growth of the coccolithophore Emiliania huxleyi in light- and nutrient-limited batch reactors: relevance for the BIOSOPE deep ecological niche of coccolithophores. Biogeosciences 13: 5983-6001.

Poulton, A.J., Adey, T.R., Balch, W.M., \& Holligan, P.M. (2007). Relating coccolithophore calcification rates to phytoplankton community dynamics: Regional differences and implications for carbon export. Deep-Sea Research Pt II 54: 538-557.

Poulton, A.J., Charalampopoulou, A., Young, J.R., Tarran, G.A., Lucas, M.I., \& Quartly, G.D. (2010). Coccolithophore dynamics in non-bloom conditions during late summer in the central Iceland Basin (July-August 2007). Limnology and Oceanography 55: 1601-1613.

Ragni, M., Airs, R.L., Leonardos, N., \& Geider, R.J. (2008). Photoinhibition of PSII in Emiliania huxleyi (Haptophyta) under high light stress: The roles of photoacclimation, photoprotection, and photorepair. Journal of Phycology 44: 670-683.

Rokitta, S.D., De Nooijer, L.J., Trimborn, S., De Vargas, C., Rost, B., \& John, U. (2011). Transcriptome analyses reveal differential gene expression patterns between the life-cycle stages of Emiliania huxleyi (Haptophyta) and reflect specialization to different ecological niches. Journal of Phycology 47: 829-838.

Rokitta, S.D., Von Dassow, P., Rost, B., \& John, U. (2014). Emiliania huxleyi endures Nlimitation with an efficient metabolic budgeting and effective ATP synthesis. BMC Genomics 15: 1051.

Rokitta, S.D., Von Dassow, P., Rost, B., \& John, U. (2016). P- and N-depletion trigger similar cellular responses to promote senescence in eukaryotic phytoplankton. Front Mar Sci 3: 109. Saez, A.G., Probert, I., Geisen, M., Quinn, P., Young, J.R., \& Medlin, L.K. (2003). Pseudocryptic speciation in coccolithophores. Proceedings of the National Academy of Science USA 100: 7163-7168.

Schaub, I., Wagner, H., Graeve, M., \& Karsten, U. (2017). Effects of prolonged darkness and temperature on the lipid metabolism in the benthic diatom Navicula perminuta from the Arctic Adventfjorden, Svalbard. Polar Biology 40: 1425-1439.

Shemi, A., Schatz, D., Fredricks, H.F., Van Mooy, B.a.S., Porat, Z., \& Vardi, A. (2016). Phosphorus starvation induces membrane remodeling and recycling in Emiliania huxleyi. New Phytologist 211: 886-898.

Stoecker, D.K. \& Lavrentyev, P.J. (2018). Mixotrophic plankton in the polar seas: a pan-Arctic review. Frontiers Marine Science 5: 292.

Supraha, L., Ljubesic, Z., Mihanovic, H., \& Henderiks, J. (2016). Coccolithophore life-cycle dynamics in a coastal Mediterranean ecosystem: seasonality and species-specific patterns. Journal of Plankton Research 38: 1178-1193.

Taylor, A.R., Russell, M.A., Harper, G.M., Collins, T.F.T., \& Brownlee, C. (2007). Dynamics of formation and secretion of heterococcoliths by Coccolithus pelagicus ssp braarudii. European Journal of Phycology 42: 125-136.

Tyrrell, T. \& Merico, A. (2004). Emiliania huxleyi: bloom observations and the conditions that induce them. Coccolithophores: From Molecular Processes to Global Impact. (Thierstein, H.R, Young J.R. eds), 75-97. Springer, Berlin. 
Tyrrell, T., Schneider, B., Charalampopoulou, A., \& Riebesell, U. (2008). Coccolithophores and calcite saturation state in the Baltic and Black Seas. Biogeosciences 5: 485-494.

Von Dassow, P., John, U., Ogata, H., Probert, I., Bendif, E., Kegel, J.U., Audic, S., Wincker, P., Da Silva, C., Claverie, J.M., Doney, S., Glover, D.M., Flores, D.M., Herrera, Y., Lescot, M., Garet-Delmas, M.J., \& De Vargas, C. (2015). Life-cycle modification in open oceans accounts for genome variability in a cosmopolitan phytoplankton. ISME Journal 9: 1365-1377. Von Dassow, P., Ogata, H., Probert, I., Wincker, P., Da Silva, C., Audic, S., Claverie, J.M., \& De Vargas, C. (2009). Transcriptome analysis of functional differentiation between haploid and diploid cells of Emiliania huxleyi, a globally significant photosynthetic calcifying cell. Genome Biology 10: R114.

Walker, C.E., Taylor, A.R., Langer, G., Durak, G.M., Heath, S., Probert, I., Tyrrell, T., Brownlee, C., \& Wheeler, G.L. (2018). The requirement for calcification differs between ecologically important coccolithophore species. New Phytologist 220: 147-162.

Wordenweber, R., Rokitta, S.D., Heidenreich, E., Corona, K., Kirschhofer, F., Fahl, K., Klocke, J.L., Kottke, T., Brenner-Weiss, G., Rost, B., Mussgnug, J.H., \& Kruse, O. (2018). Phosphorus and nitrogen starvation reveal life-cycle specific responses in the metabolome of Emiliania huxleyi (Haptophyta). Limnology and Oceanography 63: 203-226.

Young, J.R., Geisen, M., Cros, L., Kleijne, A., Sprengel, C., Probert, I., \& Østergaard, J. (2003). A guide to extant coccolithophore taxonomy. J. Nannoplankton Research 125.

Young, J.R. \& Ziveri, P. (2000). Calculation of coccolith volume and its use in calibration of carbonate flux estimates. Deep-Sea Research Part II 47: 9-11.

Zhang, Y., Bach, L.T., Schulz, K.G., \& Riebesell, U. (2015). The modulating effect of light intensity on the response of the coccolithophore Gephyrocapsa oceanica to ocean acidification. Limnology and Oceanography 60: 2145-2157.

Ziveri, P., De Bernardi, B., Baumann, K.H., Stoll, H.M., \& Mortyn, P.G. (2007). Sinking of coccolith carbonate and potential contribution to organic carbon ballasting in the deep ocean. Deep-Sea Research Pt II 54: 659-675.

Ziveri, P., Thunell, R.C., \& Rio, D. (1995). Seasonal changes in coccolithophore densities in the southern California Bight during 1991-1992. Deep-Sea Research Pt I 42: 1881-\&.

Zondervan, I. (2007). The effects of light, macronutrients, trace metals and $\mathrm{CO}_{2}$ on the production of calcium carbonate and organic carbon in coccolithophores - A review. Deep-Sea Research Pt II 54: 521-537. 
A
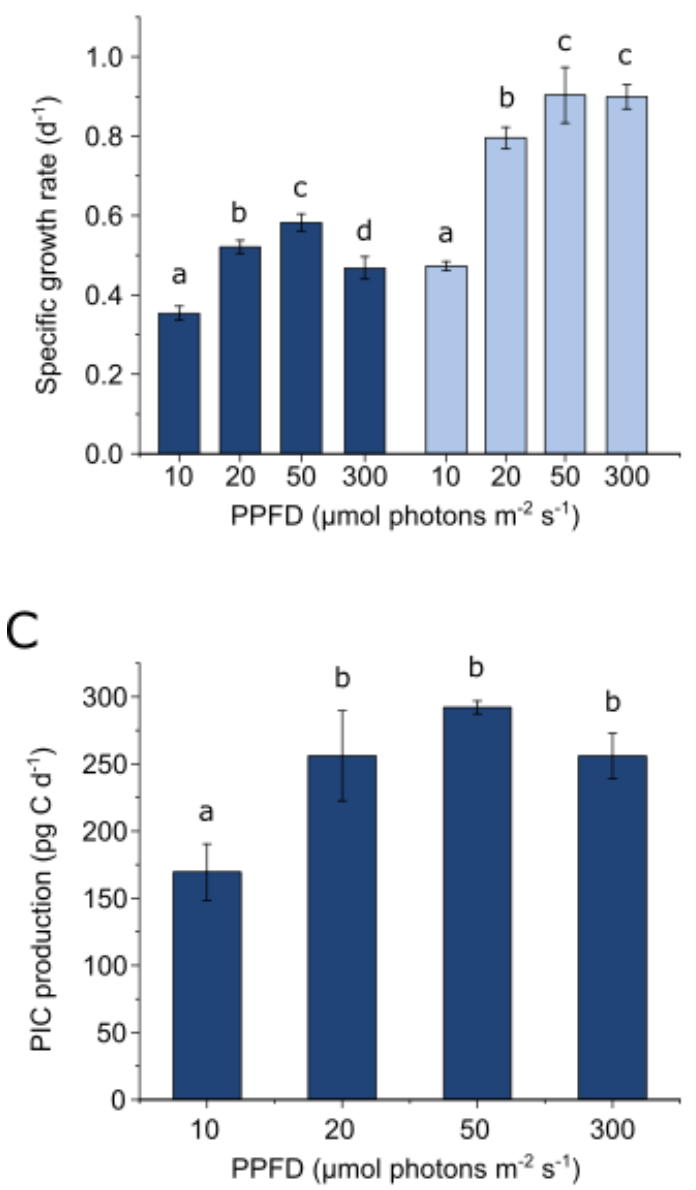

B
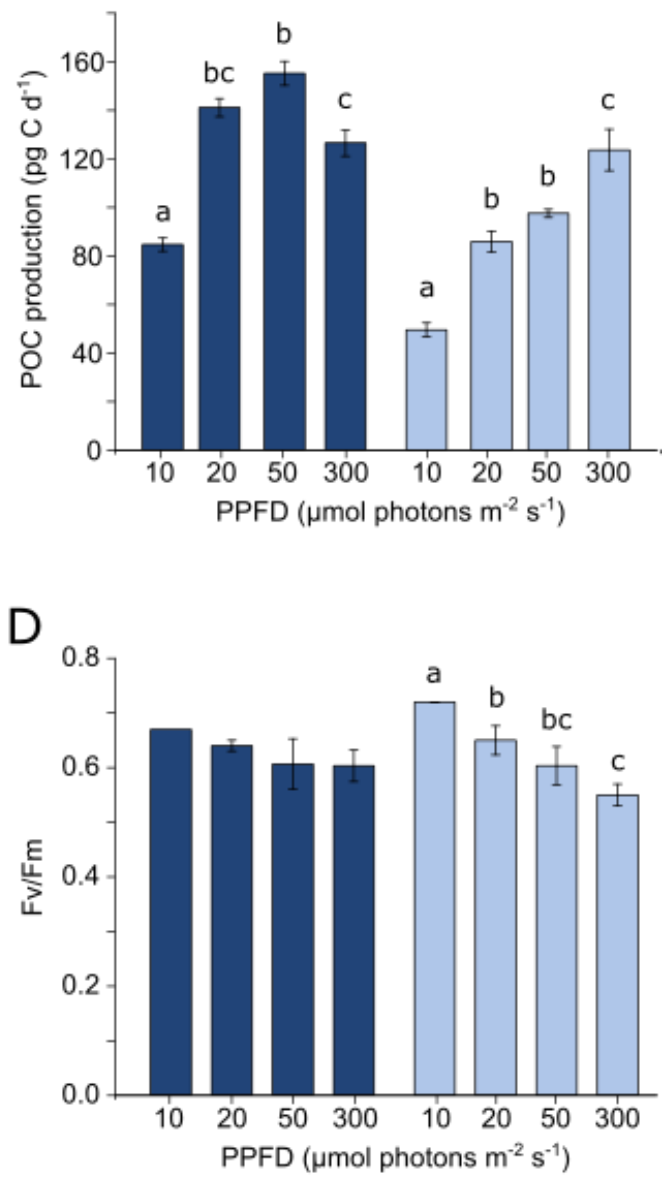

Figure 1: Physiological responses of $C$. braarudii life cycle phases to changes in irradiance.

A) Growth of heterococcolithophore (HET) PLY182g and holococcolithophore (HOL) RCC3777 at different irradiances. B) Estimated particulate organic carbon (POC) production of HET and HOL life cycle phases. C) Estimated particulate inorganic carbon (PIC) production of the HET phase. Please note that there are no PIC data for the HOL phase (see Material and Methods for details). D) Maximum quantum efficiency of PSII (Fv/Fm). In all cases n=3, error bars $=\mathrm{SD}$, letters represent treatments that are statistically different within each life cycle phase (one way ANOVA, Holm-Sidak post hoc test). 
A

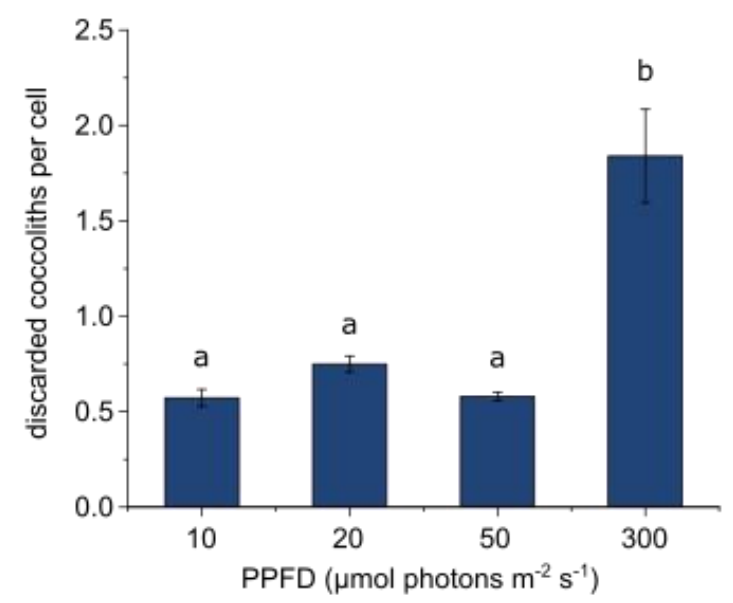

C

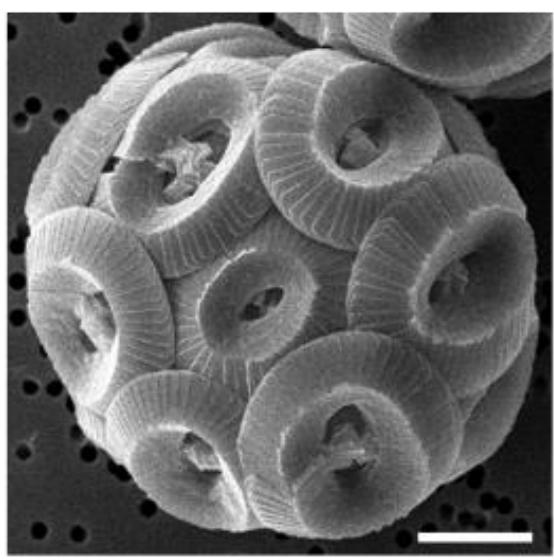

$10 \mu \mathrm{mol}$ photons $\mathrm{m}^{-2} \mathrm{~s}^{-1}$
B

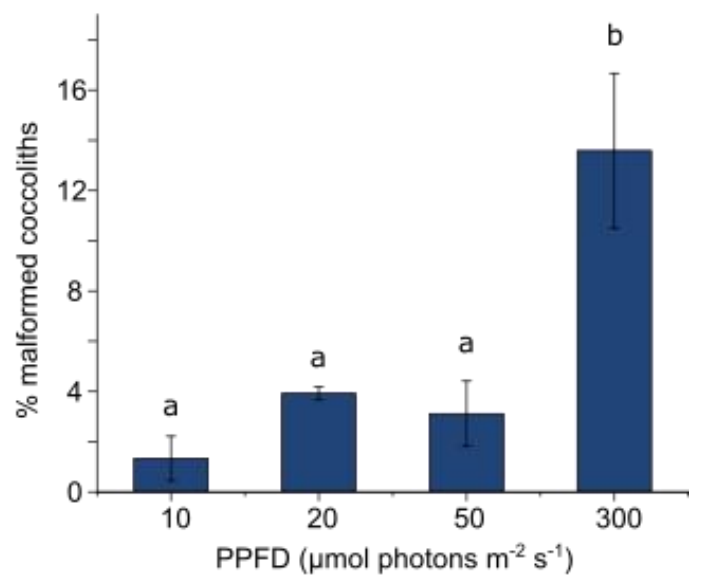

D

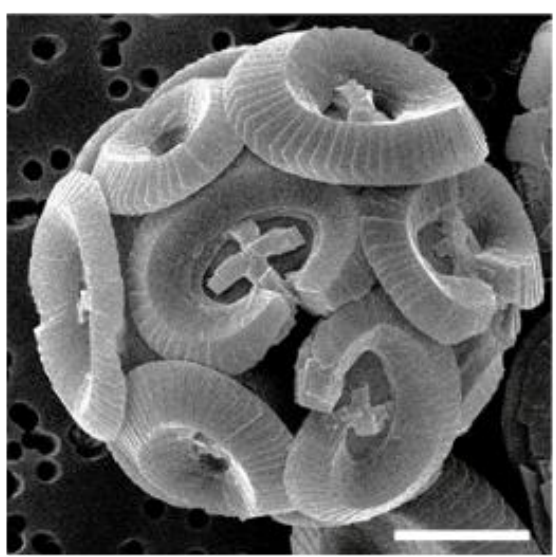

$300 \mu \mathrm{mol}$ photons $\mathrm{m}^{-2} \mathrm{~s}^{-1}$

Figure 2: Effect of irradiance on calcification in $\boldsymbol{C}$. braarudii HET. A) Number of discarded heterococcoliths per $182 \mathrm{~g}$ HET cell during growth at different irradiances, determined by light microscopy. The discarded coccoliths that do not integrate correctly into the coccosphere are often malformed. $n=3$, error bars $=S D$, letters represent treatments that are statistically different (one way ANOVA, Holm-Sidak post hoc test). B) Effect of light on coccolith morphology. The percentage of malformed heterococcoliths was determined by SEM analysis. C) Representative SEM image of a 182g HET cell grown at $10 \mu \mathrm{mol}$ photons $\mathrm{m}^{-2} \mathrm{~s}^{-1}$. Bar $=2 \mu \mathrm{m}$. D) Representative SEM image of a 182g HET cell grown at $300 \mu \mathrm{mol}$ photons $\mathrm{m}^{-2} \mathrm{~s}^{-1}$. Note the presence of malformed coccoliths. Bar $=2 \mu \mathrm{m}$. 


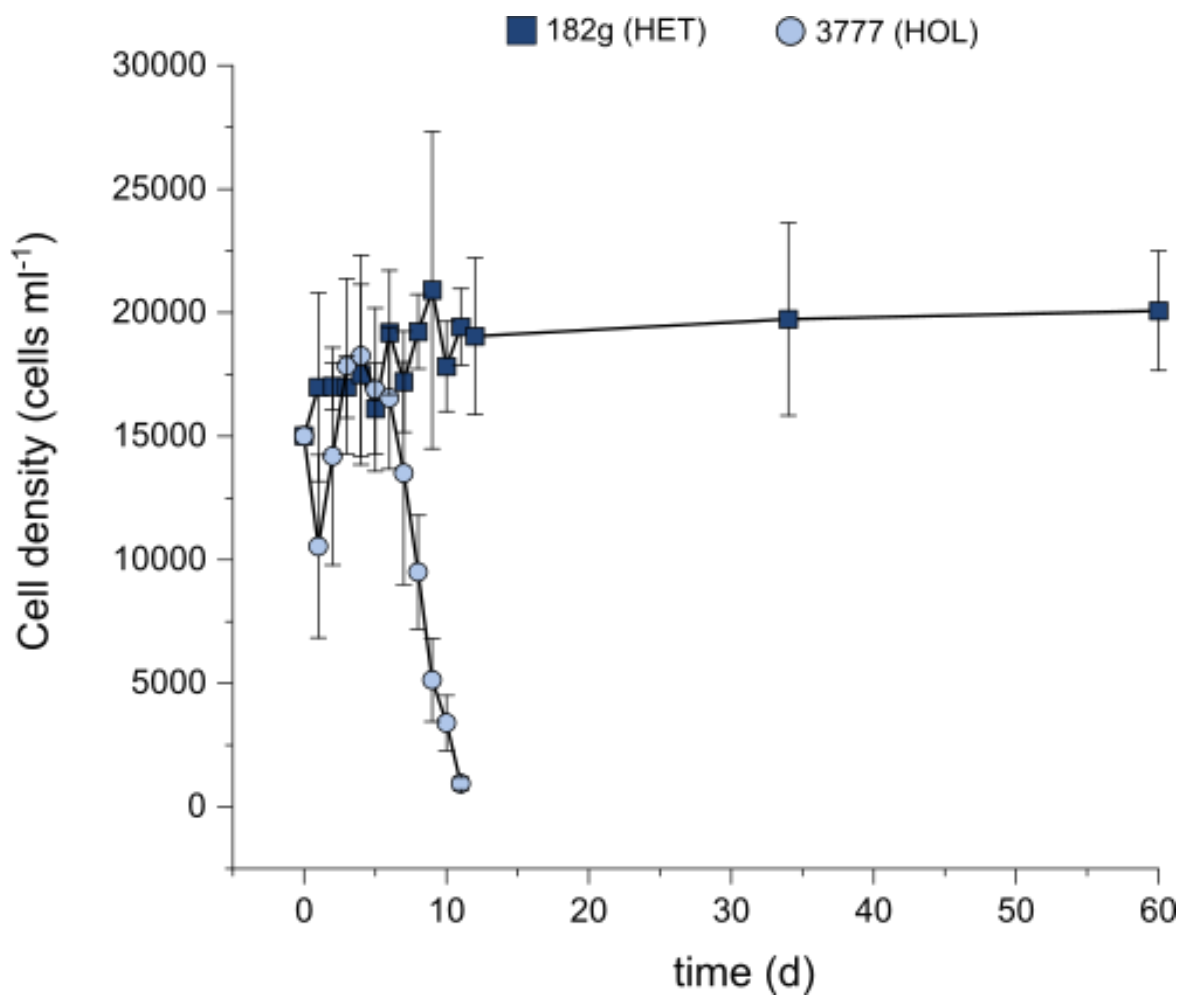

702

703 Figure 3: Survival of $\boldsymbol{C}$. braarudii in darkness. Cell density of 182g HET and 3777 HOL

704 life cycle phases during a prolonged dark period. Cells were grown to mid exponential phase

705 and then placed in continuous darkness at $\mathrm{T}=0$ for the duration of the experiment. $\mathrm{n}=3$, error

$706 \quad$ bars $=$ SD. 

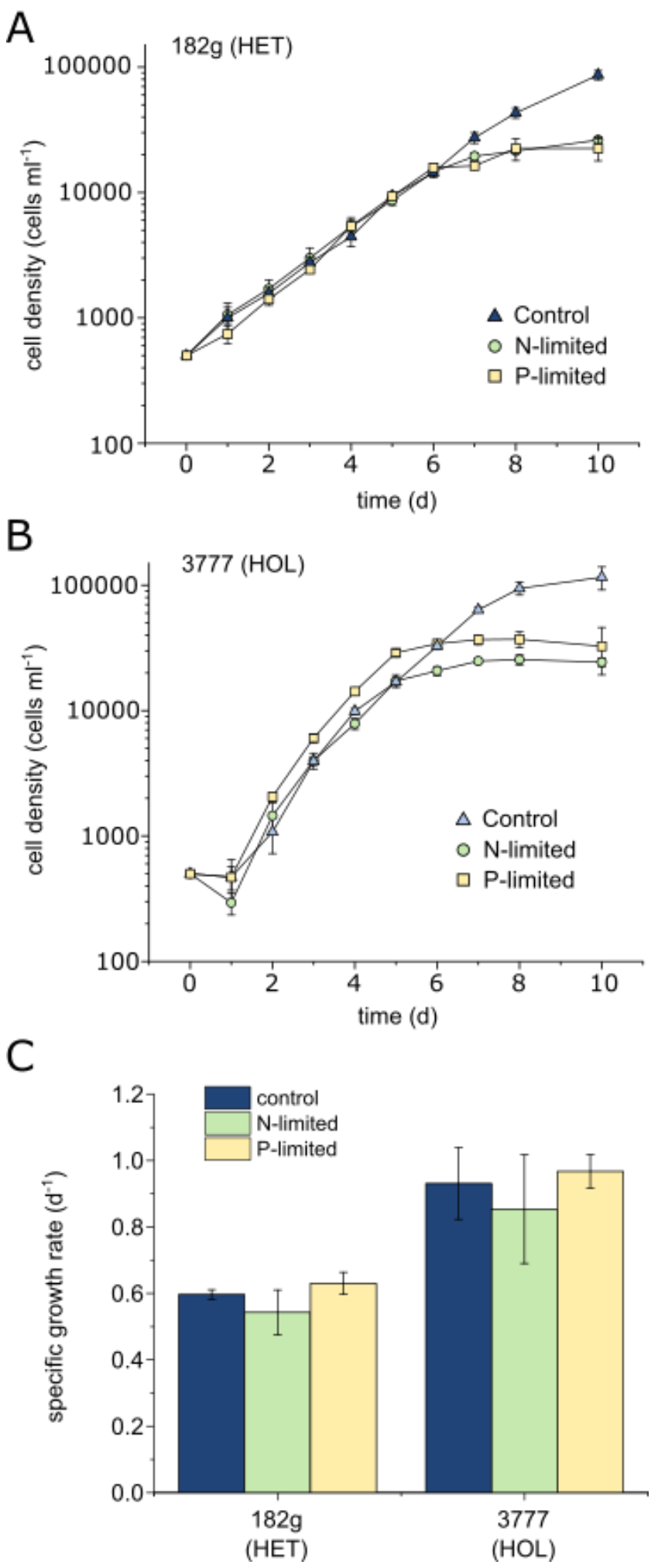

$710 \quad$ Figure 4: Response of $\boldsymbol{C}$. braarudii life cycle phases to nutrient limitation. A) Growth of

711 182g HET in nutrient limited batch cultures. N-limited initial nitrate concentration $20 \mu \mathrm{M}, \mathrm{P}$ -

712 limited initial phosphate concentration $1.5 \mu \mathrm{M}$. $\mathrm{n}=3$, error bars $=$ SD. B) Growth of 3777 
713 HOL in nutrient limited batch cultures. C) Specific growth rates calculated from the period of

714 exponential growth prior to nutrient limited growth (2-5 d for all, except 3777 HOL P-

715 limited and N-limited, 2-4 d). No significant differences were found between treatments in

716 each life cycle phase (one way ANOVA). 


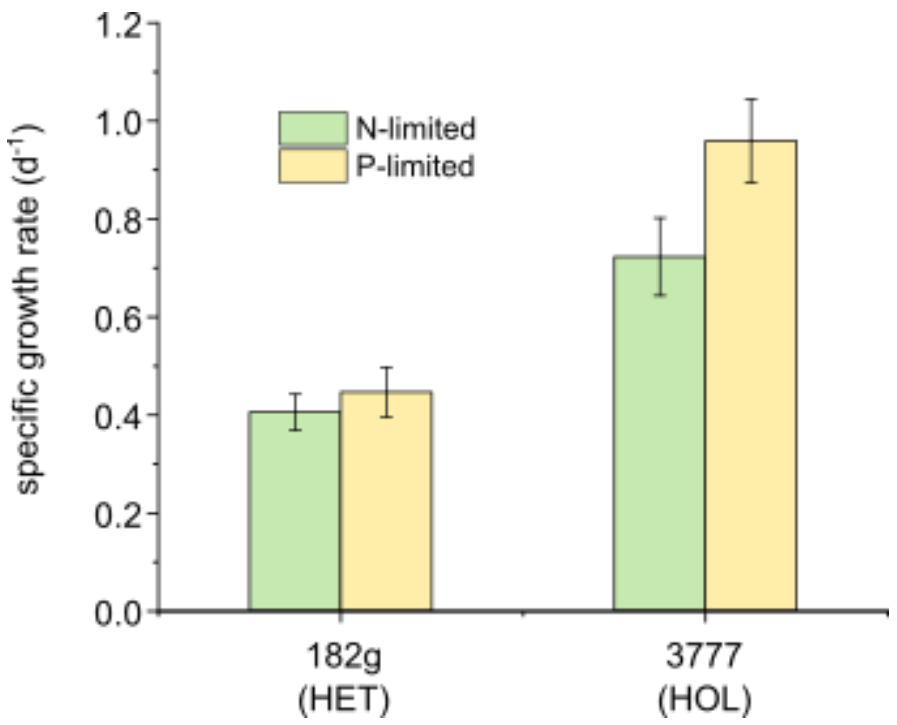

719

720 Figure 5: Growth rate of $\boldsymbol{C}$. braarudii life cycle phases following nutrient replenishment.

721 182g HET and 3777 HOL life cycle phases were grown in N-limited $(20 \mu \mathrm{M})$ or P-limited

$722(1.5 \mu \mathrm{M})$ batch cultures (as shown in Figure 4). At day 8 when growth rate had slowed,

723 cultures were diluted with an equal volume of fresh media containing $20 \mu \mathrm{M} \mathrm{N}$ (for N-limited

724 cultures) or $1.5 \mu \mathrm{M}$ P (for P-limited cultures). Growth rate was determined $24 \mathrm{~h}$ after nutrient

725 replenishment. $\mathrm{n}=3$, error bars $=\mathrm{SD}$. 
A

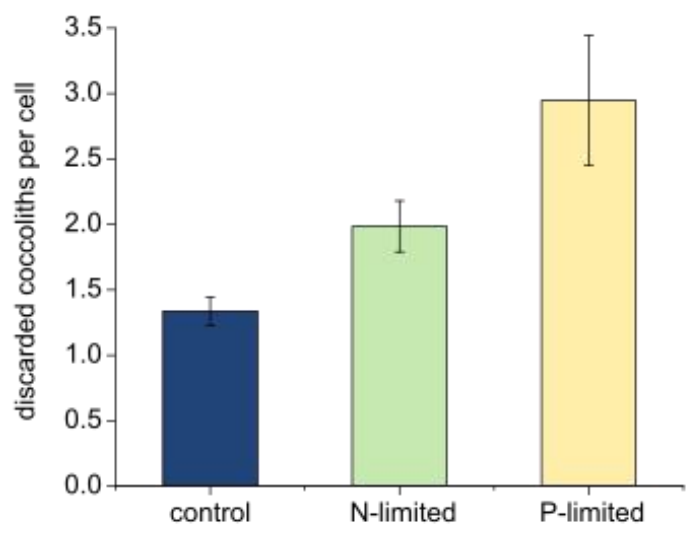

C

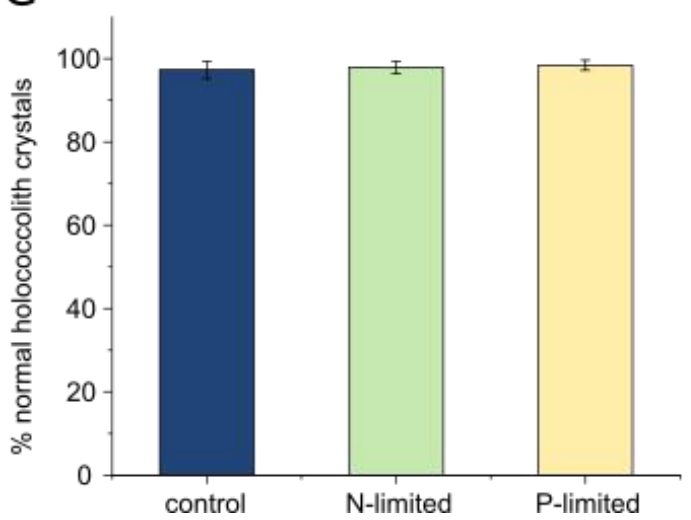

B

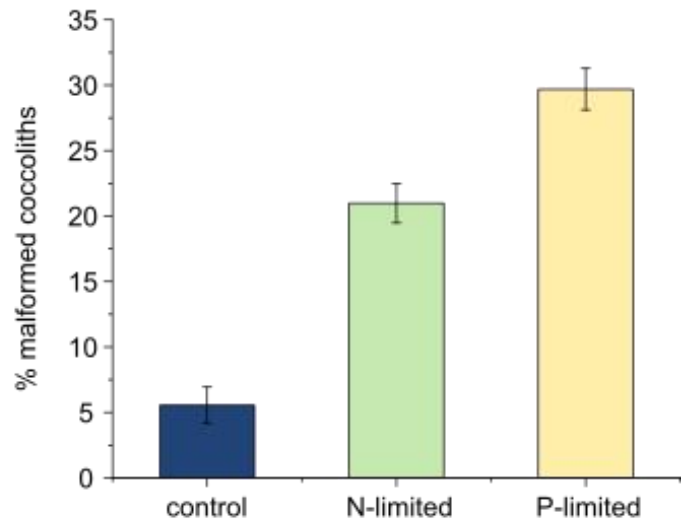

D

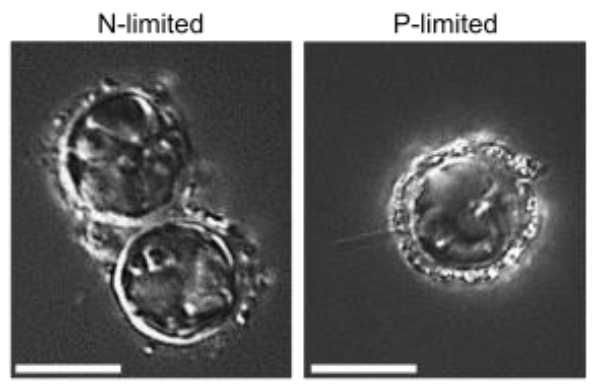

Figure 6: Effect of nutrient limitation on calcification in both life cycle phases. A)

730 Number of discarded heterococcoliths per $182 \mathrm{~g}$ HET cell during nutrient limited growth, determined by light microscopy. $n=3$, error bars $=S D$. Coccoliths that fail to integrate into the coccosphere are often malformed. B) Effect of nutrient limitation on 182g HET coccolith morphology. The percentage of malformed heterococcoliths was determined by SEM analysis. C) Effect of nutrient limitation on the morphology of crystals within holococcoliths of 3777 HOL. Crystal morphology was examined rather than the holococcolith itself, as the integrity of holococcoliths is not preserved during preparation for SEM analysis. D) Light micrographs of N- and P-limited 3777 HOL C. braarudii showing a larger, more complete coccosphere in P-limited cells, compared to N-limited cells. Scale bars $=10 \mu \mathrm{m}$. 


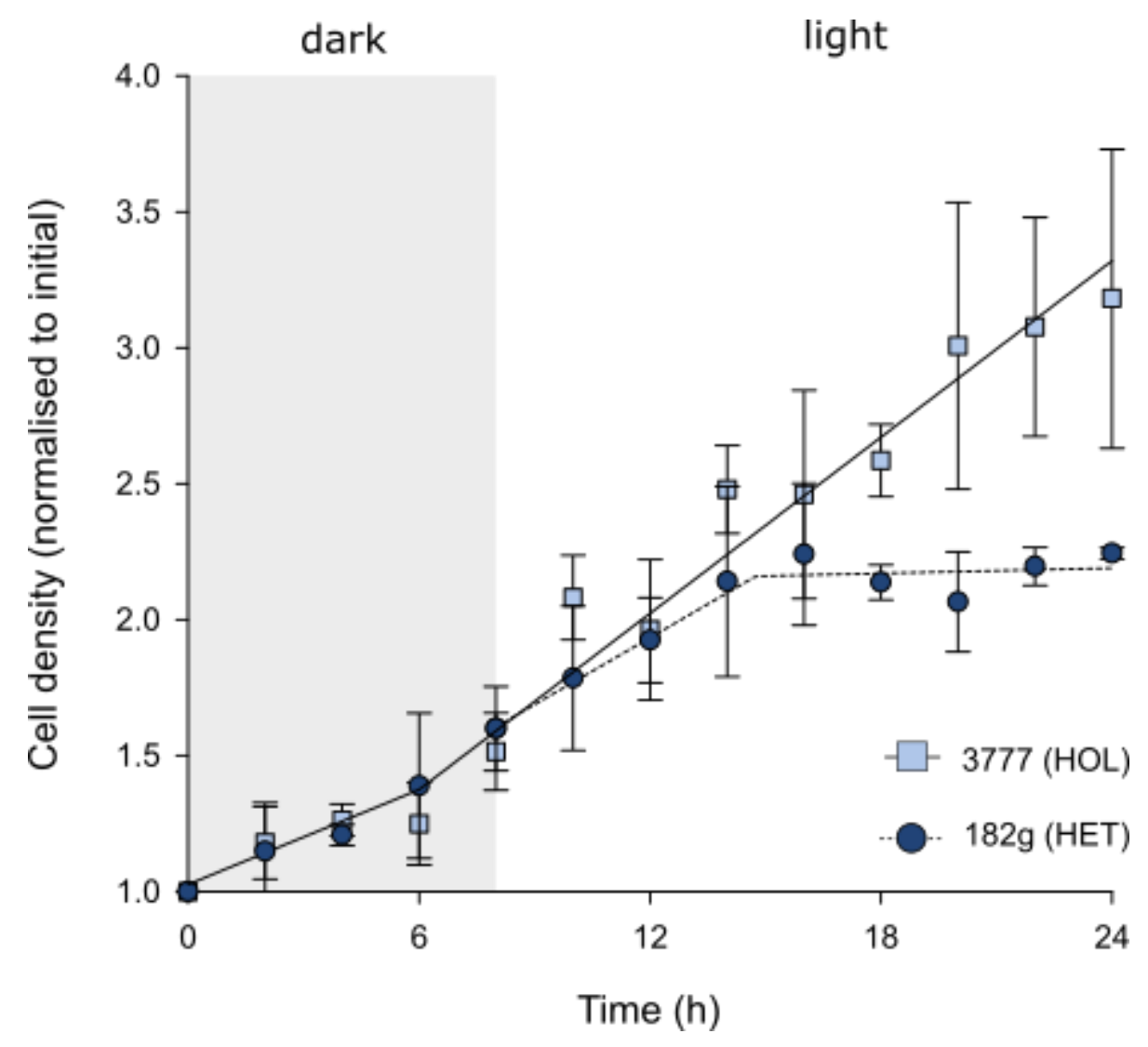

$743 \quad$ Figure 7: Timing of cell division throughout the diel cycle. Relative cell density of $182 \mathrm{~g}$

744 HET and 3777 HOL cultures are shown throughout the diel cycle (16:8, light:dark). The cell

745 densities are shown normalised to cell density at $\mathrm{T}=0$ to demonstrate the relative changes in

746 growth rate. The HET culture divides primarily in the dark phase, with cell increasing only in

747 the initial part of the light phase. In contrast, the cell density of the HOL phase increases

748 steadily throughout the diel cycle. A piecewise two segment linear regression was performed

749 to illustrate changing trends across the $24 \mathrm{~h}$ period between the life cycle phases. $\mathrm{n}=3$, error

750 bars $=S D$. 